\title{
THREE NEW LAND SHELLS OF THE GENUS OREOHELIX FROM ARIZONA
}

\author{
By William B. Marshall \\ Assistant Curator, Division of Mollusks, United States National Museum
}

The study of a collection of Oreohelix made by Mrs. Mary Vaux Walcott in the canyon at Supai, Coconino County, Ariz., in 1928, and presented by her to the United States National Museum, not only proved that they belonged to a new subspecies, but their examination entailed a close scrutiny of forms long since contained in our collection but not previously adequately studied. Among these is a new species collected by Dr. Walter Hough in Navajo County, Ariz., and a subspecies of this collected by Dr. E. A. Mearns on Clear Creek, near Winslow, Navajo County, Ariz. All of these are described below.

OREOHELIX YAVAPAI VAUXAE, new subspecies

Plate 1, Figures 1, 2, 3, 11

Shell with spire depressed, flatly conic, height of spire and depth of base about equal. Whorls sharply angulate and bearing on the periphery a prominent white carina which resembles a cord of twisted fibers because of the growth lines crossing it obliquely. This carina begins when the shell has about two whorls. The upper part of the later whorls is attached to the under side of the carina, which therefore fills the suture. It continues on the periphery of the body whorl, but is less marked behind the aperture. Early shell brownish with a few transverse growth lines and a little later with obscure elevated striae, which are obscurely granular and become stronger until about $2 \frac{1}{2}$ whorls are completed. At that point the brownish color ceases and is followed by the pale flesh color of the adult shell, and there are several rows of granules spirally arranged, and the whole surface covered with very fine spiral striae, which are most prominent just above the carina. Transverse sculpture of rather strong, retractive growth lines. Umbilicus very wide, showing all the whorls. Base rounded, smoother than the spire, with several spiral rows of minute granules. Aperture continuous, nearly round, lip simple, oblique, very slightly angulated by the periphery, a thick callus across the body whorl. Upper edge of body whorl slightly descending from the

No. 2802.-Proceedings U. S. National Museum, Vol. 76, ARt. 5 
carina at the aperture. Shell flesh color, nearly white, a brown spiral band just above the carina and one below it.

The type and 14 paratypes come from the Canyon at Supai, Coconino County, Ariz., and were collected and presented by Mrs. Charles D. Walcott, whose maiden name has been bestowed upon it.

The dimensions of the type and of those of the paratypes which are adult are as follows, in millimeters:

\begin{tabular}{|c|c|c|c|c|}
\hline Cat. No. & $\begin{array}{c}\text { Maximum } \\
\text { diameter }\end{array}$ & $\begin{array}{c}\text { Minimum } \\
\text { diameter }\end{array}$ & Height & Remarks \\
\cline { 1 - 2 } 380687 & 23.00 & 19.75 & 10.50 & Type. \\
380688 & 23.25 & 19.00 & 10.50 & Paratype. \\
380688 & 23.00 & 19.50 & 10.00 & Do. \\
380688 & 22.50 & 18.75 & 10.25 & Do. \\
380688 & 21.75 & 18.00 & 9.75 & Do. \\
380688 & 21.50 & 18.75 & 9.50 & Do. \\
380688 & 20.50 & 18.50 & 9.75 & Do. \\
380688 & 21.25 & 17.50 & 9.50 & Do. \\
380688 & 20.00 & 17.25 & 8.75 & Do. \\
& & & & \\
\hline
\end{tabular}

The prominent characteristics of this shell are the depressed conic spire, the plump round base, the cordlike white carina, the granulated striae, the wide umbilicus, and the two brown bands which show clearly on the general flesh tint of the shell. The specimens appear to be fossil or subfossil, because of the reddish mineral matter coating them in spots. This shell is evidently a subspecies of Oreohetix yavapai Pilsbry, the type of which comes from Yavapai County, which adjoins Oconino County. It is much larger than Oreohelix yavapai but has essentially the same sculpture. In dimensions it approaches but is slightly larger than Oreohetix yavapai mariae Bartsch, the type locality of which is near the mouth of Gallatin Canyon, Mont. Its sculpture is much more pronounced than that of Oreohelix yavapai mariae, in which the sculpture usual to the group is not clearly defined.

\section{OREOHELIX HOUGHI, new species}

\section{Plate 1, Figures 7, 8, 9, 10}

Shell depressed, low conic, upper surface of whorls slightly rounded. Early whorls (as shown by young shells) sharply angled, and with a white cordlike keel which fills all the sutures to the aperture, in front of which the keel disappears but the periphery for a short distance remains angular. On the back of the body whorl the angle fades out and just behind the aperture the whorl is well rounded. Upper part of each whorl attached to under side of the carina. Earliest whorls brownish, with a number of transverse riblets. Later growth pallid, with periodic transverse stripes which continue across the base to the umbilicus. Base nearly white. A faint narrow brown band just below and one just above the periphery. Spiral sculpture lacking. Transverse sculpture of numerous fine retractive growth riblets. 
Base rounded, nearly smooth, polished. Aperture oblique, nearly round, a moderate callus across the body whorl. Umbilicus wide, showing all the whorls.

The type (Cat. No. 380689, U.S.N.M.) measures: Maximum diameter, $17.5 \mathrm{~mm}$.; minimum diameter, $15 \mathrm{~mm}$; height, $9.5 \mathrm{~mm}$., and comes from Heber, Navajo County, Ariz. It and numerous paratypes (Cat. No. 334603, U.S.N.M.) were collected and presented by Dr. Walter Hough of the National Museum, for whom the species is named.

The largest of the paratypes measures: Maximum diameter, 21.75 $\mathrm{mm}$.; minimum diameter, $19 \mathrm{~mm}$; height, $12 \mathrm{~mm}$.

In depressed form and cordlike carina, this species resembles Oreohelix yavapai Pilsbry but lacks spiral sculpture and granules. Nearly all the paratypes are bleached and have lost the brown spiral band above and below the periphery.

\section{OREOHELIX HOUGHI WINSLOWENSIS, new subspecies}

Plate 1, Figures 4, 5, 6, 12

Similar to Oreohelix houghi, but averaging smaller and slightly more elevated. The corded carina is almost lacking but usually occurs for a short distance in the suture of the third whorl, and the body whorl is rounded.

The type (Cat. No. 380690, U.S.N.M.) measures: Maximum diameter, $19.5 \mathrm{~mm}$.; minimum diameter, $17.5 \mathrm{~mm}$; height, $11.75 \mathrm{~mm}$. It and 28 paratypes (Cat. No. 181309, U.S.N.M.) come from Clear Creek, near Winslow, Navajo County, Ariz., and were collected and presented by the late Dr. Edgar A. Mearns. The National Museum collection contains also 22 specimens from 12 miles south of St. Johns, in Apache County (Cat. No. 225973, U.S.N.M.); 2 specimens from Holbrook, Navajo County (Cat. No. 151459, U.S.N.M.) ; 5 specimens from near Canyon Diablo, Coconino County (Cat. No. 198518, U.S.N.M.); 13 specimens from Hardscrabble Draw, near Zuni Sacred Lake, Apache County (Cat. No. 341772, U.S.N.M.); and 25 specimens from Coon Mountain Crater, near Flagstaff, Coconino County. From this list of localities it will be seen that the species inhabits the valley of the Little Colorado River or its immediate vicinity.

\section{EXPLANATION OF THE PLATE}

Figures 1, 2, 3. Oreohelix yavapai vauxae, new subspecies, natural size.

$4,5,6$. Oreohelix houghi winslowensis, new subspecies, natural size.

$7,8,9$. Oreohelix houghi, new species, natural size.

10. Oreohelix houghi, new species, 10 diameters.

11. Oreohelix yavapai vauxae, new subspecies, 10 diameters.

12. Oreohelix houghi winslowensis, new species, 10 diameterr. 


\section{$2 \mathrm{BHL}$ Biodiversity Heritage Library}

Marshall, William B. 1929. "Three new land shells of the genus Oreohelix from Arizona." Proceedings of the United States National Museum 76(2802), 1-3. https://doi.org/10.5479/si.00963801.76-2802.1.

View This Item Online: https://www.biodiversitylibrary.org/item/88912

DOI: https://doi.org/10.5479/si.00963801.76-2802.1

Permalink: https://www.biodiversitylibrary.org/partpdf/65581

\section{Holding Institution}

Smithsonian Libraries

\section{Sponsored by}

Smithsonian

\section{Copyright \& Reuse}

Copyright Status: Public domain. The BHL considers that this work is no longer under copyright protection.

This document was created from content at the Biodiversity Heritage Library, the world's largest open access digital library for biodiversity literature and archives. Visit BHL at https://www.biodiversitylibrary.org. 